\title{
The Effect of Metacognitive Listening Strategy Instruction on Omani Grade 11 EFL Learners' Listening Comprehension and their Metacognitive Listening Awareness
}

\author{
Moza Al-Jahwari, Abdo Mohamed Al Mekhlafi, Thuwayba Al-Barwani and \\ Ahmed Abdulraheim \\ Sultan Qaboos University \\ Muscat, Oman
}

\begin{abstract}
This quasi-experimental study investigated the effect of metacognitive listening strategy instruction on Omani Grade 11 EFL learners' listening comprehension and their metacognitive listening awareness. The sample of the study included two groups (experimental and control, $n=112$ ) from grade 11 students from one of the schools in Muscat Governorate in the academic year 2017-2018. Two research instruments were used to collect data: a listening comprehension test and metacognitive awareness for listening questionnaire. The results of the study revealed that students in the experimental group outperformed their counterparts in the control group in the listening comprehension as a result of the metacognitive listening strategy instruction. Similarly, there was a statistically significant increase in the experimental group students' metacognitive listening awareness as a result of the intervention. In light of these findings, implications and recommendations for further studies were offered.
\end{abstract}

Keywords: Listening comprehension; metacognition; metacognitive awareness; metacognitive strategy instruction; teaching and learning.

\section{Introduction}

Metacognition is universally accepted to play a primary role in academic achievement (Sonowal \& Kalita, 2017; Zimmerman \& Schunk, 2001) and, more particularly, in language learning (Vandergrift, 2007; Vandergrift, Goh, Mareschal \&Tafaghodtari, 2006; Wenden, 1998). It is also considered a strong predictor for successful learning (Sonowal \& Kalita, 2017; Vandergrift \& Goh, 2012). Some researchers suggest that metacognition can compensate for students' difficulties in language learning (Goh \& Hu, 2013). Learners who are conscious about their own learning difficulties are able to find ways to resolve them (Goh, 2000). This means that metacognition is central to the language 
learning process, because it helps build self-regulated learners who can meet their own needs in different learning contexts.

In regard to language learning, listening plays a fundamental role in the process. Krashen's Input Hypothesis (1985) emphasises that comprehensible input is the primary resource for language acquisition. Thus, listening as a way of obtaining this input is considered to be of paramount importance. Morley (1984) also stresses that listening is critical not only because it is an input for learning other skills but also because it is a "premier" skill in its own right as, typically, an individual listens twice as much as they speak, four times more than they read, and five times more than they write.

Despite the importance of listening, for a long time it has been neglected in research and in language instruction. Only after the advent of the learnercentred approach and the influence of cognitive psychology in teaching and learning did listening gain more academic attention (Goh, 2008). Recent literature advocates the idea that students need to "learn how to listen" so that they can "listen to learn" (Vandergrift, 2004, p. 19). This 'how' of listening implies the assumption that listening is an active process, and that listening strategies can be explicitly taught. According to Goh (2000), there are three types of learning strategy that listeners can benefit from: cognitive, metacognitive, and socio-affective strategies. Metacognitive strategies are concerned with monitoring and evaluating learning, while cognitive strategies include the activation of schema, classifying, inferring, and note-taking. Socio-affective strategies, on the other hand, focus on asking for clarification, and confidencebuilding. Among these learning strategies, metacognitive strategies are considered the most essential (O'Malley, Chamot, Manzanares, Russo \& Küpper, 1985; Vandergrift \& Tafaghodtari, 2010), as they play a crucial role in enabling students to foresee and direct their own learning process (Gutierrez \& Schraw, 2015; Harris, 2007; Vandergrift, 1999).

In recognition of the importance of metacognition in L2 learning and, more specifically, in L2 listening, researchers have expressed a need for metacognitive listening strategy instruction. Mendelsohn (1998), for example, recommends that teachers help students to apply strategies that enable them to cope with the demands of listening. Teachers are also advised to model, for learners, the mental activities that they engage in to build their understanding of listening texts (Aldera, 2015; Goh, 2000; Goh \& Taib, 2006). Many empirical studies assert that metacognitive listening instruction enhances learners' knowledge about learning to listen and helps them to implement effective strategies for managing their comprehension, which contributes to their overall listening development (Carrier, 2003; Goh, 2002; Rahimirad, 2014; Vandergrift, 2007).

It is further argued that listening instruction that focuses on the product, rather than the process, gives no indication for the teacher regarding how the students choose an answer, or what difficulties they face. It thus does not help to improve the effectiveness of the learners' listening, or to resolve their problems (Field, 1998). Moreover, O'Malley et al. (1985) assert that, "students without 
metacognitive approaches are essentially learners without direction or opportunity to review their progress, accomplishments, and future learning directions" (p. 561). This is the case with conventional listening lessons, in which students are typically receivers of input, which may cause them to become passive and bored. These lessons also deprive them of any control over their learning. By contrast, in metacognitive strategy instruction, students are encouraged to discuss their thought process and improve their metacognitive awareness (Goh \& Taib, 2006). Teachers can also follow up on students' incorrect responses, and diagnose and overcome learners' weaknesses as listeners (Field, 1998).

In Oman, the English Language Curriculum Framework (2010), published by Ministry of Education, mentions that Grade 11 students should be able to select appropriate listening strategies like: previewing, prediction, listening for gist and guessing meaning from context. It also states that learning strategies constitute an integral part of the curriculum; and stresses the importance of independent learning, reflection and monitoring strategies. However, according to the researcher's own extensive teaching experience, there is a gap between what the curriculum framework recommends and what occurs in practice. $\mathrm{Al}$ Balushi (2017) indicates that listening lessons follow the pattern of "listen, respond and check". In other words, listening strategies are not explicitly taught to students in listening lessons; this may be one reason why students struggle when working on listening tasks or when answering listening questions in exams. Al Balushi (2017) also observes that students complain about the difficulty of listening tests because they lack strategic preparation for listening. As such, strategy instruction may provide an alternative to the conventional method of teaching listening in schools in Oman, because, as Field (1998) points out, in listening strategy instruction, gaps and problems in learners' listening skills are examined and evaluated.

Previous to the study by Al Balushi (2017), Al Busaidi (1997) investigated the different problems that Omani students face in listening, and indicated that students face problems related to teaching instruction and other problems when approaching listening comprehension tasks. In fact, Al Busaidi (1997) recommended that there are certain procedures that teachers can initiate to help students overcome their listening problems.

The literature maintains that metacognition is crucial in language learning (Carrier, 2003; Vandergrift, 2007; Vandergrift, Goh, Mareschal \&Tafaghodtari, 2006; Wenden, 1998). It also points out that there are limitations to conventional methods of listening instruction (Field, 1998; Mendelsohn, 1998; Vandergrift, 2004). Despite the importance of metacognition in language learning, its effectiveness for improving listening comprehension has not yet been explored in the Omani context. Moreover, although Omani students complain that acquiring listening skills is difficult (Al Busaidi, 1997; Al Balushi, 2017), there is a lack of studies investigating this skill in Omani schools. Therefore, a systematic investigation of the effect of metacognitive listening strategy instruction on 
improving listening comprehension and metacognitive awareness of Omani EFL learners is needed to establish its usefulness in the Omani context.

\section{Literature Review}

Research simplifies the definition of metacognition as thinking about thinking, or cognition about cognition. The term was first used by Flavell (1979), who defined it as "one's knowledge concerning one's own cognitive processes and products, or anything related to them" (p. 232). It is also used to refer to higher order thinking, which involves active monitoring and regulation of the processes involved in learning (Sonowal \& Kalita, 2017). If, for example, cognitive processes involve remembering and understanding, then metacognition involves thinking about this remembering and this understanding (Garner, 1987).

Metacognitive strategies are the processes that learners consciously use to supervise or manage their own language learning by planning what they will do, checking their progress, and then evaluating their performance $\left(\mathrm{O}^{\prime}\right.$ Malley \& Chamot, 1990). Furthermore, Oxford (1990) defines metacognitive strategies as actions that go beyond cognitive devices, and which help learners coordinate their own learning process. Similarly, Rahimirad (2014) states that metacognitive strategies refer to the "conscious management and regulation of the learning process, including planning, concentrating and monitoring" (p. 1487). According to these definitions, there are three major processes in metacognitive strategies, which are also widely accepted amongst researchers in the fields of cognitive psychology and second and foreign language learning:

1. Planning: Planning refers to the process of setting goals and selecting appropriate strategies to reach these goals $(\mathrm{Oz}, 2016)$. It includes two subcomponents, directed attention, and selective attention, which involve deciding in advance to focus on either general or specific points of language input (Nosratinia, Ghavidel \& Zaker, 2015).

2. Monitoring and Problem-solving: This refers to a learner's "on-line" awareness of their learning process whilst undertaking activities. Problemsolving involves making adjustments to one's approach as necessary, or selecting and activating more appropriate strategies (Vandergrift \& Goh, 2012).

3. Evaluation: Refers to a learner's assessment of their learning outcomes and the strategies implemented during the learning process $(\mathrm{Oz}, 2016)$.

Wenden (1998), the first researcher to apply metacognition to language learning, points out that it is very useful to guide and encourage metacognitive behaviour of students learning their second or foreign language. Subsequently, many researchers have found that metacognitive awareness can be enhanced through instruction (Goh \& Taib, 2006; Vandergrift \& Tafaghodtari, 2010). Furthermore, several studies maintain that there is a positive relationship between metacognitive awareness and academic achievement. For example, Sonowal and Kalita (2017) identified a strong positive correlation between metacognitive awareness and academic achievement in their correlational study of 150 high 
school students. Al-Alwan, Asassfeh and Al-Shboul (2013) also found a positive correlation between listening and metacognitive awareness in their study, which involved 386 Grade 10 Jordanian students, and recommended that metacognitive awareness be emphasised in listening lessons.

\subsection{Listening Comprehension}

Research has provided many definitions for listening, and there has been an observable shift from treating listening as a passive skill to giving it an active and primary role in language learning. For instance, Rost (2002) defines listening as a complex process in which listeners link what they listen to with what they already know. It is complex since, unlike reading, listening places a greater load on the memory because the listener cannot return to a text in order to check their comprehension (Ridgway, 2000). Similarly, Morely (1984) stresses that listening is an active skill that demands full participation and the focused attention of the learner. Zobler (2010) goes further, assigning importance to strategy use in listening, in a definition of listening as a cognitive process that requires both active participation and conscious construction of meaning through the use of prior knowledge, contextual information, and accessing appropriate strategies.

Listening has been described as an interactive process that requires both bottomup and top-down processes. Bottom-up processes refer to when the listener uses the information available within the speech itself to understand the meaning of the text that is listened to. By contrast, top-down processes involve the prior knowledge that the listener brings to the text (Hedge, 2000). Listening literature has tended to favour top-down over bottom-up processes, as many studies conclude that good listeners rely more on top-down processes, while less successful listeners apply bottom-up processes (Field, 2000; Rost, 2002). For example, Osada (2001) emphasised the importance of a top-down approach to listening, after finding low-level EFL Japanese students relied heavily on mental translation. The author added that they were not able to construct meaning for connected speech because they were preoccupied with processing the text word by word. However, there is some evidence that training students on bottom-up processes can produce fruitful results. For example, Kiany and Shiramiry (2002) found that the use of dictation improved the listening comprehension of Iranian EFL learners, where, after 20 sessions of listening lessons, the experimental group who were given dictation exercises outperformed the control group.

To sum up, teaching listening has to take into account both types of processes, and there must be a balance between the two approaches. In addition, the conceptualisation of listening as both an active and an interactive process lends credence to the idea that listening instruction should be assigned a primary role in equipping learners with strategies that help them regulate their own learning processes.

\subsection{Metacognitive Listening Strategy Instruction (MLSI)}

Having the ability to control one's mental processes while learning is one of the most important skills that teachers must equip their students with (Tisma, 2016). This has led scholars to assert that language instruction should focus not only on providing opportunities for language practice, but also for developing metacognitive strategies. According to Vandergrift and Goh (2012), 
metacognitive listening strategy instruction refers to, "pedagogical procedures that enable learners to increase awareness of the listening process by developing richer metacognitive knowledge about themselves as listeners, the nature and demands of listening, and strategies for listening. At the same time, learners also learn to plan, monitor, and evaluate their comprehension efforts and the progress of their overall listening development" (p. 97). Mendelsohn (1998) and Zobler (2010) also maintain that teaching that explicitly promotes and improves learners' knowledge about the listening process supports them in becoming better learners, and enables them to manage their own learning. Likewise, Gutierrez and Schraw (2015) assert that metacognitive listening instruction increases both students' learning and their metacognitive awareness.

The literature has proposed some models for teaching metacognitive strategies in general, and teaching metacognitive strategies for listening in particular. One of the models specifically developed to teach listening was proposed by Goh (1997), whose approach is based on the idea of using listening diaries as a learning and reporting tool for the purpose of developing students' metacognitive awareness and listening comprehension. The sequence of listening lessons in this approach is comprised of three stages: 1. Listen and answer; 2. Reflect; 3. Report and discuss (Goh \& Taib, 2006). In this way, the model adds reflection activities to the traditional method of teaching listening in an attempt to improve students' awareness of listening.

Another framework is the Metacognitive Pedagogical Sequence for Listening developed by Vandergrift (2004). In this framework, learners integrate the use of strategies with listening tasks, so that they are encouraged to use these strategies to regulate and achieve successful comprehension. The framework includes five stages: pre-listening, first listen, second listen, third listen, and reflection (Vandergrift \& Goh, 2012). In these stages, students are guided in planning, monitoring, problem-solving, and evaluation processes, as summarised in Table (1).

Table (1): Stages in the Metacognitive Pedagogical Sequence of Listening and Underlying Metacognitive Processes (Vandergrift \& Goh, 2012).

\begin{tabular}{cc}
\hline Pedagogical Stages & Metacognitive Processes \\
\hline $\begin{array}{c}\text { Pre-listening - Planning/predicting stage } \\
\text { First listen - First verification stage }\end{array}$ & $\begin{array}{c}\text { Planning } \\
\text { Second listen - Second verification stage }\end{array}$ \\
$\begin{array}{cc}\text { Monitoring, evaluation and problem- } \\
\text { solving }\end{array}$ \\
Third listen - Final verification stage & Monitoring and problem-solving \\
Reflection and goal-setting stage & Evaluation and planning \\
\hline
\end{tabular}

It should be noted that these metacognitive processes do not work in a linear way; rather, they interact with each other to build meaning (Vandergrift \& Goh, 2012). This sequence also enables students to utilise multiple strategies to approach the listening task, which is essential to their language development. Oxford (1994) states that when students use combinations of strategies, they will have a greater benefit than working with single strategies. The present study 
followed Vandergrift's Metacognitive Pedagogical Sequence of Listeningbecause it is a well-constructed framework for teaching listening skills. It also fits with Omani learners and the context of this study because it is practical and suitable for the level of school students. Moreover, the sequence includes both bottom-up and top-down processes, which are critical to listening.

The existing body of research, though not exhaustive, strongly suggests that metacognitive listening strategy instruction is vital to improving listening comprehension and metacognitive awareness. Given the role that metacognition plays in promoting thinking and comprehension, and to further contribute to this line of study, the present research will investigate the effectiveness of metacognitive strategies on listening comprehension and on metacognitive awareness.

\section{Methodology}

\subsection{Population and Sample}

The population of this study is Grade 11 female students enrolled in public schools in Muscat in the academic year 2017/2018. As mentioned in the Annual Educational Statistics Book published by the Ministry of Education (MoE) there are 3,886 female students for this year. The study sample is made up of Grade 11 students from Nusaiba Bint Ka'ab Post Basic School in A'Seeb. This school is a typical public school as it has all facilities that can be found in any government school in Oman. Four intact classes (112 students) were assigned to control and experimental groups. Two classes (51 students) formed the experimental group, while the other two (61 students) formed the control group.

The rationale for choosing Grade 11 students was that, at this grade, students need to be prepared for higher education where self-regulated learning is critical and the need for them to take charge of their own learning is more demanding. Only female students were involved in the study due to the fact that for religious reasons segregated educational system is followed in Oman.

Two teachers taught the two classes that formed the experimental group, and the same teachers also taught the control group classes. Having two teachers, instead of one, was intended to compensate for any idiosyncratic features that one teacher may have. The two teachers have been chosen because they taught Grade 11 and had the same educational qualifications (bachelor's degree holders from SQU) and similar levels of teaching experience (7 years and 8 years). The cooperating teachers were asked to read and sign an informed consent form. The researcher conducted a workshop to clarify the intervention and its procedures for the cooperating teachers prior to the intervention.

There were several reasons for the researcher not being involved as a teacher in this study. First, it allows the researcher to step aside and observe the instruction, which enables the data collected in the study to be triangulated. Second, it reduces the inconvenience for and reluctance of the participants, which might arise if they are taught by a researcher who they are unfamiliar 
with. Third, it ensures that there is no bias in the study, since the researcher is a bystander, so factors like researcher enthusiasm and preconceptions will not affect the study.

To ensure the equivalence of the participants, a pre-listening comprehension test was conducted with the experimental and control groups simultaneously. An independent sample t-test was run to compare the listening comprehension test scores for the experimental and control groups. As shown in Table (2), there was no statistically significant difference in the scores of the experimental group $(M$ $=8.0, S D=3.3)$ and the control group $(M=7.4, S D=2.3) ; t(110)=1.19, p=.23$, two-tailed). The results indicated the homogeneity of the two groups in terms of their level of listening comprehension prior to metacognitive listening strategy instruction.

Table 2: An Independent-Sample T-test for the Experimental and Control Groups' Pre-test Scores $(\mathrm{n}=112)$

\begin{tabular}{lllllll}
\hline Group & $\boldsymbol{N}$ & $\boldsymbol{M}^{*}$ & $\mathrm{SD}$ & $\boldsymbol{T}$ & $\mathbf{D F}$ & $\boldsymbol{p}$-value \\
\hline Experimental & 51 & 8.0 & 3.3 & & & \\
Control & 61 & 7.4 & 2.3 & & & .23 \\
\hline
\end{tabular}

The total score $=15$

The Metacognitive Awareness for Listening Questionnaire (MALQ) was also administered with the experimental and control groups, in order to determine whether both groups had an equivalent level of metacognitive listening awareness prior to the intervention. An independent sample t-test was conducted to compare the MALQ scores for the experimental and control groups, and there was no statistically significant difference in the scores for the experimental group $(M=3.2, S D=.45)$ and the control group $(M=3.16, S D=$ $.36) ; t(110)=.87, \mathrm{p}=.386$, two-tailed).

Table 3: An Independent-Sample T-test for the Experimental and Control Groups' Level of Metacognitive Awareness as Measured by MALQ Prior to Intervention ( $\mathrm{n}=$ 112)

\begin{tabular}{lllllll}
\hline Group & $\boldsymbol{N}$ & $\boldsymbol{M}$ & $\mathrm{SD}$ & $\boldsymbol{T}$ & $\mathbf{D f}$ & $\boldsymbol{p}$-value \\
\hline Experimental & 51 & 3.2 & .45 & .87 & & \\
Control & 61 & 3.16 & .36 & & & .386 \\
\hline
\end{tabular}

The results shown in Table (3) reveal that both groups were equivalent in terms of their level of metacognitive listening awareness prior to delivering the intervention.

\subsection{Research Instruments and Materials}

3.2.1Description of the Listening Comprehension Test

The listening comprehension test answered the first research question: To what extent does metacognitive listening strategy instruction affect Omani Grade 11 EFL learners' listening comprehension? The researcher developed two forms of a 
listening comprehension test, following the MoE exam specifications for Grade 11. The test was divided into two main groups of questions: Listening One required students to listen to a conversation and answer multiple-choice questions; while Listening Two was divided into two parts: fill-in-the-gap and multiple-choice questions.

One version of the test was used as a pre-test to determine the homogeneity of the experimental and control groups, while a second version was used as a posttest. The reason for having two different versions of the test was to eliminate any other variables that may have come into play with any changes in students' scores, such as memory and discussions between students after the pre-tests. This ensured more valid findings and established that any changes in students' scores were primarily the result of the intervention. The pre- and post-tests were graded by the researcher and the English language senior teacher in the school reviewed the results.

\subsubsection{Validity and Reliability of the Listening Comprehension Test}

The two versions of the listening comprehension test were validated both by academics from SQU, and other higher education institutions and practitioners from Ministry of Education (The parallelism of the two versions of the test was also verified by a panel of experts who agreed that the tests were parallel and suitable for the Grade 11 level. Based on their feedback, some minor modifications were made, such as moving the words from the alternatives to the stems of the questions, and changing the order of some items.

To establish the reliability of the listening comprehension test, it was piloted with one Grade 11 class ( 25 students) who were not involved in the study. Then, Cronbach's Alpha was calculated to determine the reliability of the test; it was found to be reliable at .77, which suggests good reliability. In addition, the pilot test helped to establish that the test was appropriate for Grade 11 students and that the audio scripts were clear.

\subsubsection{The Metacognitive Awareness for Listening Questionnaire (MALQ)}

The Metacognitive Awareness for Listening Questionnaire (MALQ) developed by Vandergrift et al. (2006) was adapted to answer the second research question: To what extent does metacognitive listening strategy instruction affect the metacognitive listening awareness of Omani Grade 11 EFL learners? The researcher obtained permission from the developers of this questionnaire to use it in this study, and they also provided an interpretation guide on how to use the data gathered from it. The MALQ evaluates, "the extent to which language learners are aware of and can regulate the process of L2 listening comprehension" (Vandergrift et al., 2006, p. 432). It consists of 21 items divided into five dimensions: planning and evaluation (items 1-5); directed attention (items 6-8); problem-solving (items 9-14); mental translation (items 15-18); and personal knowledge (items 19-21). A five-point Likert scale was used for responses to the items, where $5=$ always, $4=$ often, $3=$ sometimes, $2=$ rarely, and $1=$ never. In the original questionnaire, these dimensions were carefully selected following rigorous examinations and multiple stages of questionnaire construction. The original questionnaire was piloted with 966 learners from 
different nationalities to demonstrate the strength of the five dimensions underlying it (Vandergrift \& Goh, 2012). It should be noted that items 7, 19 and 20 are negatively stated items, and that the mental translation sub-scale (items 15-18) relates negatively to the overall scale, so these items were reverse-coded prior to the data analysis.

\subsubsection{Validity and Reliability of the MALQ}

A number of experts were asked to review the questionnaire to determine the clarity and relevance of each item. This validation panel was also asked to suggest any further items that could be added to any of the factors. Based on their feedback, some modifications were made. For example, two items were removed because of repetition, and two new items were added to the mental translation factor. The questionnaire was also translated into Arabic and validated by professional translators, English teachers, and Arabic teachers. Then, the questionnaire was piloted and Cronbach's Alpha was calculated to determine the reliability of the final MALQ, which was found to be reliable at .79 .

\subsubsection{Teacher's Manual}

Based on the literature on metacognitive listening strategy instruction (AlBalushi, 2017; Vandergrift, 2007; Vandergrift \& Goh, 2012), and on the researcher's own teaching experience, the researcher developed a teacher's manual to help the selected teachers implement the training in the right way. This manual includes the objectives of the training sessions, the definition of metacognitive strategies, the lesson sequence, and the procedures to be used. It also includes a sample of lesson plans and the listening activities to be taught in the eight sessions.

\subsubsection{Establishing the Validity of the Teacher's Manual}

The teacher's manual was validated by educational professionals, including teacher trainers, supervisors, two senior English teachers, and two English teachers, to evaluate its applicability and clarity. They all agreed that the manual was clear and applicable.

\subsubsection{The Intervention: Metacognitive Listening Strategy Instruction}

The intervention comprised eight listening lessons based on the Metacognitive Pedagogical Sequence for Listening created by Vandergrift (2004). Within this intervention, students in the experimental group were instructed on metacognitive strategies using listening passages from their syllabus (Grade 11 "Engage with English" textbooks), and the control group was exposed to the same listening passages, but without any explicit instruction on metacognitive strategies. All the listening activities taught throughout the intervention were from Grade 11 textbooks. There are variations in the listening passages presented in the book. The syllabus includes dialogues and monologues with different task demands. For example, in some tasks students were required to respond to multiple-choice or fill in the gap questions while in some tasks students had to take notes or respond to wh-questions. 
Table (4): The Stages of the Listening Lessons for the Experimental and Control Groups

\begin{tabular}{|c|c|c|}
\hline Stage & MLSI & Conventional Listening Lessons \\
\hline $\begin{array}{l}\text { Pre- } \\
\text { listening }\end{array}$ & $\begin{array}{ll}\text { - } & \text { Brainstorming } \\
\text { - } & \text { Prediction } \\
& \text { vocabulary/ content) } \\
\text { - } & \text { Planning how to listen }\end{array}$ & $\begin{array}{l}\text { - Occasional } \\
\text { brainstorming and } \\
\text { prediction of content } \\
\text { - No planning on how to } \\
\text { listen }\end{array}$ \\
\hline \multicolumn{3}{|c|}{ While listening } \\
\hline $\begin{array}{l}\text { First } \\
\text { listen }\end{array}$ & $\begin{array}{l}\text { - Listen to verify predictions and } \\
\text { to find the answers } \\
\text { - Discuss with peers } \\
\text { - Decide what parts of listening } \\
\text { need more attention }\end{array}$ & $\begin{array}{l}\text { - Listen and find the } \\
\text { answers }\end{array}$ \\
\hline $\begin{array}{l}\text { Second } \\
\text { listen }\end{array}$ & $\begin{array}{l}\text { - Revise the answers } \\
\text { - Whole-class discussion of the } \\
\text { correct answers }\end{array}$ & $\begin{array}{l}\text { - Listen and revise the } \\
\text { answers }\end{array}$ \\
\hline $\begin{array}{l}\text { Third } \\
\text { listen }\end{array}$ & $\begin{array}{l}\text { - Listen and look at the script } \\
\text { - Discussion about students' } \\
\text { problems with listening }\end{array}$ & $\begin{array}{l}\text { - Listen and revise the } \\
\text { answers }\end{array}$ \\
\hline $\begin{array}{l}\text { Post- } \\
\text { listening }\end{array}$ & $\begin{array}{l}\text { - Evaluation of performance and } \\
\text { use of strategies } \\
\text { - Planning what to do differently } \\
\text { next time }\end{array}$ & $\begin{array}{l}\text { - Whole-class discussion } \\
\text { for the correct answer } \\
\text { - No evaluation or } \\
\text { planning takes place }\end{array}$ \\
\hline
\end{tabular}

It should be noted that students in the experimental group received an orientation lesson on metacognitive listening strategies prior to the intervention in which the teacher explained the metacognitive strategies and highlighted their importance. Then, she showed the students how to use the strategies using think-aloud method.

\section{Findings and discussion}

4.1 The Effect of Metacognitive Listening Strategy Instruction on Omani Grade 11s' Listening Comprehension

To answer the first research question, 'To what extent does metacognitive listening strategy instruction affect Omani Grade 11 EFL learners' listening comprehension?', a post-listening comprehension test was administered to both groups. Then, the results of the independent sample t-test were calculated to compare the scores between the experimental and control groups. Significant differences were found in the mean scores of students in the experimental group $(M=11.33, S D=3.1)$ and control group $(M=9.57, S D=2.4) ; t(110)=3.3, p=.001$, two-tailed), as shown in Table 5. Simply put, the students in the experimental group outperformed the students in the control group. 
Table 5: Independent-Sample T-test for the Experimental and Control Groups' Posttest Scores $(\mathrm{n}=112)$

\begin{tabular}{lllllll}
\hline Group & $N$ & $M^{*}$ & $S D$ & $T$ & $D f$ & $p$-value \\
\hline Experimental & 51 & 11.33 & 3.1 & & & \\
Control & 61 & 9.57 & 2.4 & & & 001 \\
\hline
\end{tabular}

The total score $=15$

A paired-sample t-test was also conducted to further investigate the impact of metacognitive listening strategy instruction on the experimental group. Table 6 shows the results of the paired-sample t-test.

Table 6: Paired-sample T-test for the Pre- and Post-test of the Listening Comprehension Test for the Experimental Group

\begin{tabular}{cccccccc}
\hline Group & & $\mathbf{N}$ & $\mathbf{M}^{*}$ & SD & $\mathbf{T}$ & $\mathbf{d f}$ & p-value \\
\hline Experimental & Pre-test & 51 & 8.0 & 3.3 & -9.9 & 50 & .0001 \\
& Post-test & 51 & 11.33 & 3.1 & & & \\
\hline
\end{tabular}

The total score $=15$

There was a statistically significant increase in the experimental group students' scores from the pre-test to the post-test, at $t(50)=-9.9, \mathrm{p}<.05$ (two-tailed). The mean increase in the post-test was 3.3 with a $95 \%$ confidence interval ranging from -3.98 to -2.64 . The Eta-squared statistic (0.66) indicated a large effect size, according to guidelines provided by Cohen (1988). Thus, it can be concluded that MLSI had a positive effect on students' listening comprehension.

4.2 The Effect of Metacognitive Listening Strategy Instruction on EFL Grade 11s' Metacognitive Listening Awareness

To answer the second research question, 'To what extent does metacognitive listening strategy instruction affect the metacognitive listening awareness of Omani Grade 11 EFL learners?', the Metacognitive Awareness Listening Questionnaire (MALQ) adapted from Vandergrift et al. (2006)) was administered to the experimental and control groups following the intervention. The results of the independent sample t-test are displayed in Table 7 below.

Table 7: Independent-Sample T-test for the Experimental and Control Groups' PostMALQ Scores $(\mathrm{n}=\mathbf{1 1 2})$

\begin{tabular}{lllllll}
\hline Group & $\boldsymbol{N}$ & $\boldsymbol{M}$ & $\boldsymbol{S D}$ & $\boldsymbol{T}$ & $\mathbf{D F}$ & $\boldsymbol{p}$-value \\
\hline Experimental & 51 & 3.4 & .45 & 2.4 & 110 & .017 \\
Control & 61 & 3.21 & .46 & & & \\
\hline
\end{tabular}

As shown in Table 7 there was a significant difference in the mean scores between the experimental $(M=3.4, S D=.45)$ and control groups $(M=3.21, S D=$ $.46) ; t(110)=2.4, p=.017$, two-tailed). 
To further confirm the impact of metacognitive listening instruction and to gain more in-depth knowledge about its impact on every element of metacognitive listening awareness of students in the experimental group, a paired-sample t-test was used to explore the effect on overall metacognitive awareness and on every sub-scale. As shown in Table 8, there was a statistically significant increase in students' overall metacognitive listening awareness from pre-MALQ ( $M=3.2$, $S D=.45)$ to post-MALQ, $(M=3.4, S D=.34 ; t(50)=-3.23, p=.002$ (two-tailed)). This suggests that the intervention had a positive impact on the students' metacognitive listening awareness. The means and standard deviations of each sub-scale were also calculated, and are presented in Table 8. As displayed in Table 8, there was a statistically significant increase in the sub-scales of planning and evaluation, problem-solving and personal knowledge. However, directed attention and mental translation categories didn't show a statistically significant change.

Table 8: Means and Standard Deviations for Grade 11 Students' Level of Metacognitive Listening Awareness ( $\mathrm{n}=51)$

\begin{tabular}{ccccccc}
\hline Factor & \multicolumn{2}{c}{$\begin{array}{c}\text { Prior to } \\
\text { intervention }\end{array}$} & \multicolumn{2}{l}{ After intervention } & & \\
\hline & $M$ & $S D$ & $M$ & $S D$ & $t$ & $p$-value \\
Planning and Evaluation & 3.09 & .78 & 3.41 & .67 & -2.73 & .009 \\
Directed Attention & 4.19 & .89 & 4.36 & .73 & -6.26 & .120 \\
Problem-Solving & 3.50 & .84 & 3.72 & .62 & -2.16 & .035 \\
Mental Translation & 2.43 & .91 & 2.27 & .97 & 1.21 & .231 \\
Personal Knowledge & 2.99 & .94 & 3.24 & .66 & -2.38 & .021 \\
Overall Awareness & 3.2 & .45 & 3.40 & .34 & -3.23 & .002 \\
\hline
\end{tabular}

Table 9 below shows the scale for interpreting the overall mean of the mean scores for the metacognitive processes included in the MALQ. The overall awareness of students prior to the intervention fell in the moderate level category, and increased to a high level following the intervention. However, directed attention $(M=4.19)$ and problem-solving $(M=3.50)$ fell into the high level category prior to the intervention. This section will provide details for every category in the MALQ questionnaire.

Table 9: Scale for Interpreting the Means for Level of Metacognitive Listening Awareness

\begin{tabular}{|c|c|}
\hline Scale Value & Level of Metacognitive Listening Awareness \\
\hline $1-1.79$ & Very Low \\
\hline $1.8-2.59$ & Low \\
\hline $2.6-3.39$ & Moderate \\
\hline $3.4-4.19$ & High \\
\hline $4.2-5$ & Very High \\
\hline
\end{tabular}

Planning and Evaluation

Planning and evaluation refers to the strategies that assist learners in planning and preparing for listening, as well as evaluating their performance after 
listening. Table10 shows the means and standard deviations for the items related to this category.

Table 10: Means and Standard Deviations for the Planning and Evaluation Sub-scale in the MALQ $(n=51)$

\begin{tabular}{|c|c|c|c|c|}
\hline \multirow[t]{2}{*}{ Statement } & \multicolumn{2}{|c|}{$\begin{array}{l}\text { Before } \\
\text { intervention }\end{array}$} & \multicolumn{2}{|c|}{$\begin{array}{l}\text { After } \\
\text { intervention }\end{array}$} \\
\hline & M & SD & M & SD \\
\hline $\begin{array}{l}\text { 1. Before I start to listen, I have a plan in my mind for how I } \\
\text { am going to listen. }\end{array}$ & 3.27 & 1.28 & 3.59 & 1.15 \\
\hline $\begin{array}{l}\text { 2. Before listening, I think of similar texts that I may have } \\
\text { listened to. }\end{array}$ & 2.09 & 1.1 & 2.49 & 1.01 \\
\hline 3. I have a goal in mind as I listen to English texts. & 3.31 & 1.28 & 3.75 & 1.04 \\
\hline $\begin{array}{l}\text { 4. As I listen, I periodically ask myself if I am satisfied with } \\
\text { my level of comprehension. }\end{array}$ & 3.31 & 1.36 & 3.37 & 1.13 \\
\hline $\begin{array}{l}\text { 5. After listening, I think of how I listened, and about what I } \\
\text { might do differently next time. }\end{array}$ & 3.47 & 1.27 & 3.86 & 1.13 \\
\hline Overall Planning and Evaluation & 3.09 & .78 & 3.41 & 67 \\
\hline
\end{tabular}

Table 10 shows that most of the items are convergent, and that there is a noticeable increase in the means for all items from pre-intervention to postintervention. The highest mean increase was for statement 3 'I have a goal in mind as I listen to English texts'. This was because the MLSI students were adequately prepared to listen, as the teachers encouraged students to think of the purpose of their listening, predict the listening topic, and set a goal before they started to listen. They were also instructed on evaluating their performance in every MLSI lesson. Throughout the intervention, students were required to reflect on their listening process and identify areas for improvement, which explains the improved means for statements 4 and 5 .

\section{Directed Attention}

Directed attention concerns the strategies needed to focus attention on the listening task. Table 11 presents the means and the standard deviations for the items related to this category.

Table 11: Means and Standard Deviations for the Directed Attention Sub-scale in the $\operatorname{MALQ}(n=51)$

\begin{tabular}{|c|c|c|c|c|}
\hline \multirow[t]{2}{*}{ Statement } & \multicolumn{2}{|c|}{$\begin{array}{c}\text { Before } \\
\text { intervention }\end{array}$} & \multicolumn{2}{|c|}{$\begin{array}{c}\text { After } \\
\text { intervention }\end{array}$} \\
\hline & $\mathbf{M}$ & SD & $\mathbf{M}$ & SD \\
\hline $\begin{array}{l}\text { 6. I try to focus more on the text when I have trouble } \\
\text { understanding it. }\end{array}$ & 4.28 & 1.13 & 4.59 & .82 \\
\hline $\begin{array}{l}\text { 7. When I have difficulty understanding what I hear, I give } \\
\text { up and stop listening. }\end{array}$ & 3.98 & 1.20 & 3.96 & 1.39 \\
\hline 8. I try to focus again when I lose concentration. & 4.18 & 1.08 & 4.53 & .73 \\
\hline Overall Directed Attention & 4.19 & .89 & 4.36 & .73 \\
\hline
\end{tabular}


There was a slight increase in the overall mean for this category. However, this increase is not significant (see Table 8). The overall mean score for directed attention $(M=4.19)$ was the highest amongst the MALQ sub-scales. It has been well-documented in the literature that language learners across different levels give priority to directed attention when receiving language input (Goh \& $\mathrm{Hu}$, 2013). This popular use of directed attention may explain the high mean prior to the intervention, and indeed priority was also given to the attention factor in the present study. When students were asked to evaluate their performance and what they would do differently in the next listening, in the post-listening stage, the majority of them reported that they would try to concentrate more on the message and pay more attention to the listening script.

Moreover, the insignificant increase for directed attention in the post-MALQ scores can be attributed to the fact that these students had already reached a high level of directed attention, so their involvement in this training made little improvement to their attention.

\section{Problem-solving}

Problem-solving strategies help students make inferences when they are not able to hear or understand a certain word; they are also related to monitoring and evaluating comprehension while listening. As shown in Table 12, the mean increased from a moderate level before the intervention $(M=3.09)$ to a high level $(M=3.41)$ after the intervention. The highest increase was for item 14 'When I guess the meaning of a word, I think back to everything else that I have heard to see if my guess makes sense' from $(M=3.62)$ in the pre-MALQ to $(M=4.09)$ in the post-MALQ. This indicates that students acquired more complex metacognitive strategies. To utilise such strategies, students need to concentrate on the text, construct meaning, and consider their own thinking as they are trying to make sense of what they are listening to (Goh \& Hu, 2013).

Table 12: Means and Standard Deviations for the Problem-solving subscale in the $\operatorname{MALQ}(\mathrm{n}=51)$

\begin{tabular}{|c|c|c|c|c|}
\hline \multirow[t]{2}{*}{ Statement } & \multicolumn{2}{|c|}{$\begin{array}{c}\text { Before } \\
\text { intervention }\end{array}$} & \multicolumn{2}{|c|}{$\begin{array}{c}\text { After } \\
\text { intervention }\end{array}$} \\
\hline & $\mathrm{M}$ & SD & M & SD \\
\hline $\begin{array}{l}\text { 9. I use the general idea of the text to help me guess the } \\
\text { meaning of the words that I don't understand. }\end{array}$ & 3.57 & 1.4 & 3.71 & 1.15 \\
\hline $\begin{array}{l}\text { 10. As I listen, I quickly adjust my interpretation if I } \\
\text { realise that it is not correct. }\end{array}$ & 3.84 & 1.25 & 3.96 & 1.07 \\
\hline $\begin{array}{l}\text { 11. As I listen, I compare what I understand with what I } \\
\text { already know about the topic. }\end{array}$ & 2.68 & 1.08 & 2.82 & 1.09 \\
\hline $\begin{array}{l}\text { 12. I use my experience and knowledge to help me } \\
\text { understand the text. }\end{array}$ & 3.43 & 1.22 & 3.75 & 1.12 \\
\hline $\begin{array}{l}\text { 13. I use the words I understand to guess the meaning of } \\
\text { the words I don't understand. }\end{array}$ & 3.88 & 1.14 & 4.09 & .98 \\
\hline $\begin{array}{l}\text { 14. When I guess the meaning of a word, I think back to } \\
\text { everything else that I have heard, to see if my guess } \\
\text { makes sense. }\end{array}$ & 3.62 & 1.2 & 4.04 & .97 \\
\hline Overall Problem-solving & 3.50 & .84 & 3.72 & .62 \\
\hline
\end{tabular}


In the MLSI undertaken for this study, teachers prompted students to use problem-solving strategies. For example, teachers did not accept the answers only, but went further, asking students how they had reached their answers. Students became more aware of their own thinking. Moreover, the noticing activity in the final listen helped students to identify their own mistakes, and they were able to explain their perception problems as they compared the written form with what they had heard. This can clearly explain the significant improvement seen in problem-solving strategies.

\section{Mental Translation}

Mental translation refers to the strategies students use to translate the input to their first language. According to Vandergrift et al. (2006), EFL listeners must avoid mental translation in order to become more effective listeners. As shown in Table 13, there was a decrease in the overall mean from $(M=2.43)$ in the preMALQ to $(M=2.27)$ in the post-MALQ.

Table 13: Means and Standard Deviations for the Mental Translation Sub-scale in $\operatorname{MALQ}(\mathrm{n}=51)$

\begin{tabular}{|c|c|c|c|c|}
\hline & \multicolumn{2}{|c|}{$\begin{array}{c}\text { Before } \\
\text { intervention }\end{array}$} & \multicolumn{2}{|c|}{$\begin{array}{c}\text { After } \\
\text { intervention }\end{array}$} \\
\hline & $M$ & $S D$ & $M$ & $S D$ \\
\hline 15. I translate every word in my mind as I listen & 2.73 & 1.32 & 2.63 & 1.3 \\
\hline 16. I translate key words as I listen. & 2.37 & 1.34 & 2.02 & 1.19 \\
\hline $\begin{array}{l}\text { 17. I think about the information I am listening to in both } \\
\text { languages (Arabic and English). }\end{array}$ & 2.41 & 1.08 & 2.14 & 1.09 \\
\hline $\begin{array}{l}\text { 18. As I listen, I use Arabic when I guess the meaning of } \\
\text { unknown words. }\end{array}$ & 2.24 & 1.2 & 2.30 & 1.17 \\
\hline Overall Mental Translation & 2.43 & .91 & 2.27 & .97 \\
\hline
\end{tabular}

Though not statistically significant (see Table 9), this decrease is desirable since it means that students attempted to focus on connecting speech to construct meaning. Osada (2001) notes that when learners are busy with translation, they preoccupy themselves by processing the input word-by-word, making it difficult for them to understand the message conveyed. The insignificant decrease might be attributed to the fact that eight weeks may not be sufficient time to significantly decrease the use of mental translation, since students use it frequently. The researcher noticed that evidence of their use of mental translation was present in their listening test papers, as some of the students wrote Arabic translations beside the given questions, so more time might be needed to avoid this strategy and see a significant change. The same issue was highlighted by Al Balushi (2017), who stated that the participants in her study translated the components and the given instructions into Arabic before they attempted to answer.

\section{Personal Knowledge}

The category of personal knowledge relates to listeners' perceptions regarding the difficulty of listening, and their confidence in L2 listening. Table 14 shows 
the descriptive statistics for this category. As shown in Table 14, the mean score for personal knowledge improved from $(M=2.99)$ before the intervention to $(M$ $=3.24$ ) after the intervention.

Table 14: Means and Standard Deviations for the Personal Knowledge Sub-scale in the MALQ $(n=51)$

\begin{tabular}{lcccc}
\hline & \multicolumn{2}{c}{$\begin{array}{c}\text { Before } \\
\text { intervention }\end{array}$} & \multicolumn{2}{c}{$\begin{array}{c}\text { After } \\
\text { intervention }\end{array}$} \\
\hline & $\mathrm{M}$ & $\mathrm{SD}$ & $\mathrm{M}$ & $\mathrm{SD}$ \\
$\begin{array}{l}\text { 19. In English, I find that listening is more difficult than } \\
\text { reading, speaking, or writing. }\end{array}$ & 2.80 & 1.4 & 3.10 & 1.4 \\
$\begin{array}{l}\text { 20. I feel that listening comprehension in English is a } \\
\text { challenge for me. }\end{array}$ & 2.76 & 1.43 & 2.72 & 1.54 \\
$\begin{array}{l}\text { 21. I feel confident when I listen to English texts. } \\
\text { Overall Personal Knowledge }\end{array}$ & 3.41 & 1.2 & 3.90 & 1.10 \\
& 2.99 & .94 & 3.24 & .66 \\
\hline
\end{tabular}

Students' responses to statement 21 'I feel confident when I listen to English texts' increased from $(M=3.41)$ in the pre-MALQ to $(M=3.9)$ in the postMALQ. This suggests that students have gained some confidence in listening as a result of the instruction. Another improvement in their personal knowledge is seen in statement 20 ' I feel that listening comprehension in English is a challenge for me', which decreased from $(M=2.76)$ in the pre-MALQ to $(M=2.72)$ in the post-MALQ. However, their perception of listening as being more difficult than reading, speaking, or writing increased from $(M=2.8)$ in the pre-MALQ to $(M=$ 3.1) in the post-MALQ .This may be because the students became more aware of the complex nature of listening skills, and that this requires greater memory and attention capacities when compared to reading and writing skills.

Regarding personal knowledge, it can be concluded that MLSI has a positive impact in improving students' confidence in L2, as Harputlu and Ceylan (2014) maintain that confidence and self-encouragement are of key importance in listening comprehension. This also echoes Goh's (2008) position on MLSI that it promotes students' confidence and makes them more comfortable with the listening process.

\section{Conclusion}

The results of this study have highlighted the positive effect of metacognitive listening strategy instruction on students' listening comprehension and their metacognitive listening awareness, lending support to the existing body of research that investigates the importance of MLSI. Thus, these findings extend our knowledge about the significant role of listening process-based approach on helping students use metacognitive strategies to regulate and achieve successful comprehension. Engaging students in the strategies of planning, monitoring, problem-solving and evaluation makes them more active listeners, rather than passive receivers for input. 


\section{Recommendations}

The findings of the present study imply the need for a move away from the conventional methods of teaching listening towards MLSI. Students need to be taught how to approach listening texts, and how to monitor and evaluate their performance. To enable this, teachers may be made aware of the importance of metacognition and learning strategies. Teachers' pre-service training programmes may prioritise metacognition, and equip student teachers with strategies for how to apply them in classrooms. Such training will improve teachers' practices in teaching listening and other language skills. Furthermore, professional development workshops and in-service training courses offered by the Ministry of Education should take into account the role of metacognition in learning, and should provide teachers with techniques to implement metacognitive strategies in the classroom. Teachers themselves need to seek out opportunities to encourage their students to use these strategies. Technological innovations can be incorporated within listening lessons to foster learning and make it more interesting for students. The finding that students' performance improved as a result of only an eight-week MLSI intervention encourages the implementation of this instruction in daily lessons to gain more fruitful results and help students improve both their language skills and metacognitive awareness.

\section{References}

Al-Alwan, A., Asassfeh, S., \& Al-Shboul, Y. (2013). EFL learners' listening comprehension and awareness of metacognitive strategies: How are they related?. International Education Studies, 6(9), 31-39. http://dx.doi.org/10.5539/ies.v6n9p31

Al Balushi, A. (2017) The effect of using test-taking strategies in Omani grade 11 students' performance in listening comprehension tests and their perceptions of these strategies. (Unpublished M.A. thesis). Sultan Qaboos University, Muscat, Sultanate of Oman.

Al-Busaidi, S. (1997). An investigation into the causes of students' listening comprehension problems in English at secondary level in two schools in Sultanate of Oman. (Unpublished M.A thesis). Exeter University, England.

Aldera, A. (2015). Investigating multimedia strategies to aid L2 listening comprehension in EFL environment. Theory and Practice in Language Studies, 5(10), 1983-1988. http://dx.doi.org/10.17507/tpls.0510.02

Carrier, K. A. (2003). Improving high school English language learners' second language listening through strategy instruction. Bilingual Research Journal, 27(3), 383-408.

Field, J. (1998). Skills and strategies: Towards a new methodology for listening. ELT Journal, 2(52), 110-118.

Field, J. (2000). Not waving but drowning: A reply to Tony Ridgway. ELT Journal: English Language Teaching Journal, 54(2), 186-195. Retrieved from: https://academic.oup.com/eltj/article-abstract/54/2/186/413646/Notwaving-but-drowing-a-reply-to-Tony-Ridgway

Flavell, J. H. (1979). Metacognition and cognitive monitoring: A new area of cognitivedevelopmental inquiry. American Psychologist, 34, 906-911.

Garner, R. (1987) Metacognition and Reading Comprehension. Norwood, New Jersey: Ablex. 
Goh, C. (1997). Metacognitive awareness and second language listeners. ELT Journal, 51(4), 361-69. Retrieved from https://academic.oup.com/eltj/articleabstract/51/4/361/433846.

Goh, C. (2000). A cognitive perspective on language learners' listening comprehension Problems. System, 28(1), 55-75.

Goh, C. (2002). Exploring listening comprehension tactics and their interaction patterns. System, 30, 185-206.

Goh, C. (2008). Metacognitive instruction for second language listening development: theory, practice and research implications. RELC Journal: A Journal of Language Teaching And Research, 39(2), 188-213. http://dx.doi.org/10.1177/0033688208092184

Goh, C. \& Hu, G. (2013). Exploring the relationship between metacognitive awareness and listening performance with questionnaire data. Language Awareness, 23(3), 255-274. http://dx.doi.org/10.1080/09658416.2013.769558.

Goh, C. \& Taib, Y. (2006). Metacognitive instruction in listening for young learners. ELT Journal, 60(3), 222-232.

Gutierrez, A. P., \& Schraw, G. (2015). Effects of Strategy Training and Incentives on Students' Performance, Confidence, and Calibration. Journal Of Experimental Education, 83(3), 386-404.

Harputlu, L., \& Ceylan, E. (2014). The effects of motivation and metacognitive strategy use on EFL listening proficiency. Procedia - Social and Behavioural Sciences,158, 124-131.

Harris, V. (2007). Exploring progression: Reading and listening strategy instruction with near-beginner learners of French. Language Learning Journal, 35(2), 189-204.

Hedge, T. (2000). Teaching and learning in the language classroom. Oxford: Oxford University Press.

Kiany, G. R., \& Shiramiry, E. (2002). The effect of frequent dictation on the listening comprehension ability of elementary EFL learners. TESL Canada Journal, 20(1), 57-63.

Krashen, S. D. (1985) .The Input Hypothesis: Issues and Implications: London: Longman.

Mendelsohn, D. (1998). Teaching listening. Annual Review of Applied Linguistics,18, 81101.

Ministry of Education, Oman (2010). The English Language Curriculum Framework, Oman: Directorate General of Curriculum Development.

Ministry of Education, Oman (2017). The Annual Educational Statistics Book, Oman: Department of Statistics and Educational Information.

Morley, J. (1984) Listening and language learning in ESL: developing self-study activities for listening comprehension. Orlando, Florida: Harcourt Brace Jovanovich.

Nosratinia, M., Ghavidel, S., \& Zaker, A. (2015). Teaching metacognitive strategies through Anderson's Model: Does it affect EFL learners' listening comprehension?. Theory and Practice in Language Studies, 5(6), 1233-1243. http://dx.doi.org/10.17507/tpls.0506.16

O'Malley, J. M., \& Chamot, A. U. (1990). Learning Strategies in Second Language Acquisition. New York: Cambridge University Press.

O'Malley, J. M., Chamot, A.U., Manzanares, G. S., Russo, R. P., \& Küpper, L. (1985). Learning strategy applications with students of English as a second language. TESOL Quarterly, 19(3), 557-584.

Osada, N. (2001). What strategy do less proficient learners employ in listening comprehension? A reappraisal of bottom-up and top-down processing. Journal of the Pan-Pacific Association of Applied Linguistics, 5(1), 73-90. 
Oxford, R. (1990). Language Learning Strategies: What every teacher should know. Boston: Heinle \& Heinle.

Oxford, R. (1994). Language learning strategies: An Update. ERIC Clearinghouse on Languages and Linguistics, 1-4.

Oz, H. (2016). The importance of personality traits in students' perceptions of metacognitive awareness. Procedia - Social and Behavioural Sciences, 232, 655-667. http://dx.doi.org/10.1016/j.sbspro.2016.10.090

Rahimirad, M. (2014). The impact of metacognitive strategy instruction on the listening performance of university students. Procedia- Social and Behavioural Sciences, 98, 1485-1491.

Ridgway, T. (2000). Listening strategies - I beg your pardon?. ELT Journal, 54(2),

179- 185. https://doi.org/10.1093/elt/54.2.179

Rost, M. (2002), Teaching and Researching Listening. London: Longman.

Sonowal, M., \& Kalita, M. (2017). A study on metacognitive awareness and academic achievement of Higher Secondary level students of Dibrugarh town of Assam, India. Clarion: International Multidisciplinary Journal, 6(1), 69-74. http:/ /dx.doi.org/10.5958/2277-937X.2017.00012.0

Tišma, D. (2016). Improving listening comprehension skills relying on metacognitive strategies - focus on vocabulary and specific 12 instruction. Zbornik: Institut Za Pedagoška Istraživanja, 48(2), 301-320. http://dx.doi.org/10.2298/ZIPI1602301J

Vandergrift, L. (1999). Facilitating second language listening comprehension: Acquiring successful strategies. ELT Journal, 53(3), 168-176.

Vandergrift, L. (2004). Learning to listen or listening to learn. Annual Review of Applied Linguistics, 24(1), 3-25.

Vandergrift, L. (2007). Recent developments in second and foreign language listening comprehension research. Language Teaching, 40(3), 191-210.

Vandergrift, L., \& Goh, C. C. M. (2012). Teaching and Learning Second Language Listening: Metacognition in Action. New York: Routledge.

Vandergrift, L. Goh, C. C. M., Mareschal, C., \& Tafaghodtari, M. H. (2006). The Metacognitive Awareness Listening Questionnaire (MALQ): Development and Validation. Language Learning, 56(3), 431-462.

Vandergrift, L., \& Tafaghodtari, M. H. (2010). Teaching L2 learners how to listen does make a difference: An empirical study. Language Learning, 60(2), 470-497. http://dx.doi.org/10.1111/j.1467-9922.2009.00559.x

Wenden, A. (1998). Metacognitive knowledge and language learning. Applied Linguistics, 19(4), 515-537.

Zimmerman, H. J., \& Schunk, D. H. (2001). Self-regulated Learning and Academic Achievement. Mahwah, NJ: Erlbaum.

Zobler, C. (2010). Effects of Listening Strategies Instruction on Listening Comprehension, Oral Proficiency, and Metacognition on Second Language Learners.Education Dissertations. 16. Retrieved from http://repository.wcsu.edu/educationdis/16. 